\title{
Discriminative and predictive ability for screening the Korean dysphonic patients using self-reported questionnaires
}

\author{
Yeon Woo Lee, Geun Hyo Kim \\ Department of Otorhinolaryngology-Head and Neck Surgery and Biomedical Research Institute, Pusan National University Hospital, Busan, Korea
}

Purpose: The purpose of this study was to verify the discriminative and predictive abilities of the Korean versions of the Voice Handicap Index (K-VHI), Voice-Related Quality of Life (KVRQOL), and Voice Catastrophization Index (K-VCI) for dysphonia screening.

Methods: A total of 132 and 244 subjects in the control and case groups, respectively, completed the $\mathrm{K}-\mathrm{VHI}, \mathrm{K}-\mathrm{VRQOL}$, and $\mathrm{K}-\mathrm{VCI}$. Using the different types of questionnaires, we tried to verify whether age, symptom duration, type of diagnosis, and gender affected the results, and analyzed the cut-off points for screening dysphonic patients.

Results: The mean scores of questionnaires were not affected by factors such as age, symptom duration, type of diagnosis, or gender. All questionnaires showed a significant correlation with one another. The mean $\mathrm{K}-\mathrm{VHI}$ and $\mathrm{K}-\mathrm{VCI}$ scores of the case group were significantly higher than those of the control group. The mean K-VRQOL score of the case group was significantly lower than that of the control group. The cut-off points for the K-VHI, K-VRQOL, and $\mathrm{K}-\mathrm{VCl}$ were $12.1,91$, and 6.1 , respectively. The data showed relatively high sensitivity, specificity, and area under the curve values at each cut-off point (above 0.9), indicating excellent accuracy and a high power of discrimination.

Conclusions: The cut-off points identified in our study for the $\mathrm{K}-\mathrm{VHI}, \mathrm{K}-\mathrm{VRQOL}$, and $\mathrm{K}-\mathrm{VCI}$ for distinguishing patients with voice disorders from the control group can be used as criteria to screen for Korean dysphonic patients.

Keywords: Dysphonia, Quality of life, Catastrophization, Self-reported questionnaires

\section{INTRODUCTION}

Voice disorders impair patients' quality of life (QOL) [1]. Various voice evaluation tools have been introduced and used; of these, self-reported questionnaires on voice disorders provide insights into why patients with similar voice disorders experience different levels of QOL-related decrements and thus, assess the impact of voice disorders on QOL [2-5]. Patients with dysphonia may lose time from work, seek disability claims, and utilize health care resources, thus exacerbating societal economic hardships and decreasing productivity [1]. Considering these problems, it is essential to determine the complete impact resulting from the disability in patients with voice disorders [6,7]. A number of self-reported questionnaires have been developed, including, the Voice Handicap Index (VHI) [5], the VHI-10 [8], and the Voice-Related Quality of Life (VRQOL) [9]. The VHI and VRQOL are reported to valid tools to assess the QOL and have been translated

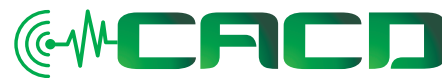 \\ Received: March 4, 2020 \\ Revision: May 4, 2020 \\ Accepted: September 1, 2020 \\ Correspondence: \\ Geun Hyo Kim \\ Department of Otorhinolaryngology- \\ Head and Neck Surgery and Biomedical \\ Research Institute Pusan National \\ University Hospital, 179 Gudeok-ro, \\ Seo-gu, Busan 49241, Korea \\ Tel: +82-51-240-7543 \\ Fax: +82-51-240-7336 \\ E-mail: pusanghkim@gmail.com
}

C 2020 The Korean Association of SpeechLanguage Pathologists

This is an Open Access article distributed under the terms of the Creative Commons Attribution NonCommercial License (https://creativecommons.org/ licenses/by-nc/4.0/) which permits unrestricted noncommercial use, distribution, and reproduction in any medium, provided the original work is properly cited. 
into multiple languages [10-17].

Recently, there have been many studies on the effects of speech problems on catastrophization and QOL, as well as the relationship among them [18]. Catastrophization is a phenomenon of cognitive distortion frequently associated with anxiety and depressive disorders, and is characterized by concern, fear, and inability to divert attention from pain [19,20]. It relates to the patients' inner world, thoughts, and beliefs; whereas QOL relates to the outer world and general well-being in different aspects of life, including environmental inter actions. More specifically, catastrophization is distinct from QOL, handicap, or disability which relates to aspects of the patient's outer life. Patients with voice disorders were found to have a higher prevalence of depression, anxiety, personality, and other psychiatric disorders [18,21-23]. Although the concepts of QOL and catastrophization may be different, individuals who catastrophize tend to have poorer QOL and higher levels of disability than those who do not [18]. Shoffel-Havakuk et al. developed the Voice Catastrophization Index (VCI) based on the Pain Catastrophizing Scale [18,24], and verified its validity and reliability for estimating catastrophization in patients with voice disorders.

Many studies report that the three questionnaires are valid tools $[9,18,25]$. However, the validity and reliability of self-reported questionnaires do not predict the accuracy of diagnosis, case identification, risky behaviors, the patients' inner world (e.g., catastrophization), or QOL. Some studies have emphasized the diagnostic capability of the VHI in clinical practice and its ability to differentiate dysphonic from normal voices $[5,6,26]$. Other studies have evaluated self-reported questionnaires as a screening tool to identify dysphonic voices $[27,28]$. Contrary to studies which use the VHI and VRQOL, studies on the diagnostic capability of the VCI are lacking. Most importantly, there are no studies which analyze the diagnostic capability of the VCI in Korean dysphonic patients. Combined, the diagnostic capability of the three questionnaires is able to verify the effect of a voice disorder on a patient's outer (QOL) and inner (catastrophization) life.

In terms of the diagnostic capabilities of self-reported questionnaires, it is important to analyze their sensitivity (the proportion of patients with the disease who have a positive test), specificity (the proportion of patients without the disease who have a negative test), and the cut-off point for differentiating dysphonic from normal voice. In the present study, we evaluated and compared three questionnaires (K-VHI, K-VRQOL, and K-VCI) to [1] determine the cut-off points at which the tests differentiate dysphonic from normal voice; and [2] determine the diagnostic capability of the three questionnaires for Korean patients.

\section{METHODS}

\section{Patients}

The present study was approved by the Institutional Review Board of Pusan National University Hospital. A total of 403 patients who visited the Pusan National University Hospital laryngology clinic, in South Korea between January 2019 and August 2019 were selected. All diagnoses were made by one otolaryngologist and one speech language pathologist using laryngoendoscopy. Patients who could not complete the required questionnaires and patients with a psychiatric history were excluded.

Based on these exclusion criteria, a total of 376 patients were included in this study and all of them could complete the required questionnaires independently. Next, the patients were classified into two groups: the control group and the case group. The control group $(\mathrm{n}=132)$ included all new patients with swallowing problems (foreign bodies in the larynx, coughing, and chocking when eating or drinking), tonsillitis, adenoid hypertrophy, and cough (without voice complaints). The case group $(n=244)$ included all new patients with either clinically perceived dysphonia or a patient-reported voice complaint. All patient information is included in Table 1. There was no significant difference in the age ( $p$ value $=0.875$ ) or in the gender ratio between the two groups ( $p$ value $=0.713$ ).

Table 1. The information on patients

\begin{tabular}{|c|c|c|}
\hline & $\begin{array}{l}\text { Control group patients } \\
\text { (Without voice problem) }\end{array}$ & $\begin{array}{l}\text { Case group patients } \\
\text { (With voice problem) }\end{array}$ \\
\hline Total number & 132 & 244 \\
\hline Mean age \pm SD & $57.2 \pm 11.1$ & $56.8 \pm 11.3$ \\
\hline Male/Female (\%) & $62(46.9) / 70(53.1)$ & $107(43.8) / 137(56.2)$ \\
\hline \multirow[t]{8}{*}{ Diagnosis } & Dysphagia 35 (26.5\%) & Vocal nodule $47(19.3 \%)$ \\
\hline & Thyroid nodule 33 (25.0\%) & Vocal polyp 45 (18.4\%) \\
\hline & Tonsillitis 30 (22.7\%) & Vocal cyst 34 (13.9\%) \\
\hline & Cough $12(9.1 \%)$ & Primary MTD 28 (11.5\%) \\
\hline & Adenoid hypertrophy & Vocal palsy 27 (11.2\%) \\
\hline & $10(7.6 \%)$ & Atrophy 25 (10.2\%) \\
\hline & Others 12 (9.1\%) & Reinke's edema 23 (9.4\%) \\
\hline & & Vocal granuloma 15 (6.1\%) \\
\hline
\end{tabular}

MTD, Muscle tension dysphonia. 


\section{Study design}

The Korean version of the VHI (K-VHI) [10], VRQOL (KVRQOL) [29], and VCI (K-VCI) [25] were used and all patients completed these questionnaires at the initial visit.

The K-VHI included 30 items, divided into three subtypes: functional, physical, and emotional. For each item, the patient was asked to indicate severe degrees of thoughts and feelings on a five-point numerical scale $(0=$ not at all; $1=$ to a slight degree; $2=$ to a moderate degree; $3=$ to a great degree; $4=$ all the time). The maximal possible score is 120 , and the minimal score is 0 ; a high score indicates a high severe degree of voice disorder. The K-VHI questionnaire is presented in Appendix A.

The K-VRQOL include 10 items; for each item, the patient was asked to indicate how severe their thoughts and feelings were on a five-point numerical scale ( $1=$ not at all; $2=$ to a slight degree; $3=$ to a moderate degree; $4=$ to a great degree; $5=$ all the time). The standard score for the K-VRQOL was calculated using the following formula [29]:

Standard score for the K-VRQOL $=100-\frac{(\text { Raw score }-10) \times 100)}{40}$

The maximum possible score is 100 (good V-RQOL), and the minimum possible score is 0 (poor V-RQOL). The K-VRQOL questionnaire is presented in Appendix B.

The K-VCI include 13 items, divided into three dimensions: rumination, magnification, and helplessness. Rumination (items 8-11) involves how consumed the patient's thoughts are by their symptoms. Magnification (items 6, 7, and 13) indicates exaggeration of the impacts of their symptoms and thoughts about a much poorer prognosis. Helplessness (items 1-5 and 12) involves feeling that nothing will ever improve their situation. For each item, patients were asked to indicate severe degrees of their thoughts and feelings using a five-point numerical scale $(0=$ not at all; $1=$ to a slight degree; $2=$ to a moderate degree; $3=$ to a great degree; $4=$ all the time). The maximum possible score is 52 , and the minimum possible score is 0 ; a higher score represents higher levels of catastrophization of the voice condition [18]. The K-VCI questionnaire is presented in Appendix C.

\section{Statistical analyses}

The Statistical Package for the Social Sciences version 18.0 package (IBM Corp., Armonk, NY) was used for all statistical analyses. We carried out the statistical analyses in four stages, as follows.

Stage 1: Although many studies have reported that the three questionnaires are valid tools, it was necessary to confirm var- ious factors including age, symptom duration, diagnosis type, and gender could influence the results of this study. For this, a multiple regression analysis of the mean scores for the K-VHI, K-VRQOL, and K-VCI was performed to verify whether age, symptom duration, type of diagnosis, and gender affected the results. Using the criteria outlined by Shoffel-Havakuk et al. [18], age and symptom duration were classified as follows: age above or below 60 years and symptom duration of more or less than 1 year, respectively.

Stage 2: To verify linear correlations between the K-VHI and its three subtypes (functional, physical, and emotional), the KVRQOL, and the K-VCI, we used Pearson correlation coefficients.

Stage 3: We used the Mann-Whitney U test to compare the mean K-VHI scores with its three subtypes (functional, physical, and emotional), the K-VRQOL, and the K-VCI among the control and case group.

Stage 4: We used the receiver operating characteristics (ROC) curve to determine the sensitivity, specificity and the area under the curve (AUC) for each cut-off point and domain of the K-VHI, K-VRQOL, and K-VCI. The accuracy level of the AUC ranged from excellent to poor (0.9- 1: excellent, 0.8-0.90: good, $0.7-0.8$ : fair, and 0.6-0.7: poor; a value of poor and $0.5-0.6$ : failure). P-values less than 0.05 were considered to be statistically significant.

\section{RESULTS}

The effects of age, symptom duration, type of diagnosis, and gender on questionnaire scores

A multiple regression analysis showed that the mean K-VHI, K-VRQOL, and K-VCI scores were not affected by age, symptom duration, diagnosis type, or gender in the case group (Table 2). The K-VHI scores were not significantly affected by age above 60 years ( $p=0.672$ ), symptom duration longer than 1 year $(p=0.515)$, diagnosis type $(p=0.421)$, or gender $(p=0.295)$; the K-VRQOL scores were not significantly affected by age above 60 years ( $p=0.377$ ), symptom duration longer than 1 year $(p=0.170)$, diagnosis type $(p=0.385)$, or gender $(p=0.742)$; and the K-VCI scores were not significantly affected by age above 60 years $(p=0.431)$, symptom duration longer than 1 year $(p=0.292)$, diagnosis type $(p=0.116)$, or gender $(p=0.330)$.

\section{Correlations between the K-VHI, K-VROOL, and K-VCI}

Correlations between the K-VHI and its three subtype (func- 
Table 2. Multiple regression analysis for the effects of factors on the K-VHI, K-VROOL, and K-VCl in case group

\begin{tabular}{|c|c|c|c|c|c|c|c|c|c|c|}
\hline & & \multicolumn{2}{|c|}{$\begin{array}{c}\text { Unstandardized } \\
\text { Coefficients }\end{array}$} & \multirow{2}{*}{$\begin{array}{c}\begin{array}{c}\text { Standardized } \\
\text { Coefficients }\end{array} \\
\text { Beta }\end{array}$} & \multirow[t]{2}{*}{$t$} & \multirow[t]{2}{*}{$R$} & \multirow[t]{2}{*}{$R^{2}$} & \multirow[t]{2}{*}{ Adj. $R^{2}$} & \multirow[t]{2}{*}{ Sig. } & \multirow[t]{2}{*}{ VIF } \\
\hline & & Beta & Std. Error & & & & & & & \\
\hline \multirow[t]{5}{*}{$\mathrm{K}-\mathrm{VHI}$} & (Constant) & 38.423 & 8.878 & & 4.328 & 0.116 & 0.013 & -0.009 & 0.000 & \\
\hline & Age & -2.140 & 5.045 & -0.033 & -0.424 & & & & 0.672 & 1.099 \\
\hline & Duration & -3.007 & 4.606 & -0.050 & -0.653 & & & & 0.515 & 1.037 \\
\hline & Diagnosis & -0.816 & 1.012 & -0.063 & -0.807 & & & & 0.421 & 1.097 \\
\hline & Gender & 4.786 & 4.553 & 0.079 & 1.051 & & & & 0.295 & 1.012 \\
\hline \multirow[t]{5}{*}{ K-VROOL } & (Constant) & 65.472 & 7.780 & & 8.415 & 0.147 & 0.022 & -0.001 & 0.000 & \\
\hline & Age & 3.912 & 4.421 & 0.069 & 0.885 & & & & 0.377 & 1.099 \\
\hline & Duration & 5.558 & 4.037 & 0.105 & 1.377 & & & & 0.170 & 1.037 \\
\hline & Diagnosis & 0.772 & 0.887 & 0.068 & 0.871 & & & & 0.385 & 1.097 \\
\hline & Gender & -1.314 & 3.990 & -0.025 & -0.329 & & & & 0.742 & 1.012 \\
\hline \multirow[t]{5}{*}{$\mathrm{K}-\mathrm{VCl}$} & (Constant) & 21.806 & 4.278 & & 5.098 & 0.170 & 0.029 & 0.007 & 0.000 & \\
\hline & Age & -1.919 & 2.431 & -0.062 & -0.789 & & & & 0.431 & 1.099 \\
\hline & Duration & -2.346 & 2.219 & -0.080 & -1.057 & & & & 0.292 & 1.037 \\
\hline & Diagnosis & -0.771 & 0.487 & -0.123 & -1.581 & & & & 0.116 & 1.097 \\
\hline & Gender & 2.144 & 2.194 & 0.073 & 0.977 & & & & 0.330 & 1.012 \\
\hline
\end{tabular}

K-VHI, Korean version of Voice Handicap Index; K-VROOL, Korean version of Voice-Related Quality of Life; K-VCl, Korean version of Voice Catastrophization Index; Age, age above or below 60 years; Duration, symptom duration of more or less than 1 year; Diagnosis, diagnosis types.

Table 3. Correlations between the K-VHI, three subtypes of K-VHI, K-VROOL, and K-VCI

\begin{tabular}{lcccccc} 
& K-VHI(T) & K-VHI(F) & K-VHI(P) & K-VHI(E) & K-VROOL & K-VCI \\
\hline K-VHI(T) & - & $0.893^{* * *}$ & $0.897^{* * *}$ & $0.901^{* * *}$ & $-0.889^{* * *}$ & $0.890^{* * *}$ \\
K-VHI(F) & - & $0.857^{* * *}$ & $0.851^{* * *}$ & $-0.869^{* * *}$ & $0.812^{* * *}$ \\
K-VHI(P) & & - & $0.861^{* * *}$ & $-0.857^{* * *}$ & $0.862^{* * *}$ \\
K-VHI(E) & & & - & $-0.871^{* * *}$ & $0.862^{* * *}$ \\
K-VROOL & & & & - & $-0.882^{* * *}$
\end{tabular}

K-VHI(T), Korean version of Voice Handicap Index (Total); K-VHI(F), Korean version of Voice Handicap Index (Functional); K-VHI(P), Korean version of Voice Handicap Index (Physical); K-VHI(E), Korean version of Voice Handicap Index (Emotional); K-VROOL, Korean version of Voice-Related Quality of Life; K-VCl, Korean version of Voice Catastrophization Index.

${ }^{* * *} p<0.001$.

tional, physical, and emotional), K-VRQOL, and K-VCI are presented in Table 3. All questionnaires used in the present study showed a significant correlation with each other $(p<0.001)$.

\section{Descriptive statistics for the K-VHI, K-VR0OL, and K-VCI}

To compare the mean scores of the K-VHI and its three subtype (functional, physical, and emotional), K-VRQOL, and KVCI between the control and case groups, we used the MannWhitney U test (Table 4). The mean K-VHI and K-VCI scores for the case group with voice disorders were significantly higher than those of the control group (without voice disor- ders) $(p<0.001)$. The mean K-VRQOL scores for the case group were significantly lower than those of the control group $(p<0.001)$.

Cut-off points for the three questionnaires at which dysphonia was differentiated from normal voice

Based on the ROC curve test in our study; the cut-off points for K-VHI, K-VRQOL, and K-VCI that differentiate dysphonic voice from normal voice were 12.1, 91, and 6.1 points, respectively (Table 5). The AUC values for the three questionnaires were above 0.9 , and the sensitivity and specificity for the three questionnaires were above 0.9 . 
Table 4. Descriptive statistics of K-VHI, three subtypes of K-VHI, K-VROOL, and K-VCl in two groups

\begin{tabular}{|c|c|c|c|c|}
\hline & & Control (Without voice problem) & Case (With voice problem) & $p$ value \\
\hline \multirow[t]{2}{*}{ K-VHI(T) } & Mean \pm SD & $5.8 \pm 3.9$ & $40.1 \pm 31.2$ & $<0.001$ \\
\hline & Median (IOR) & $5(3-10.2)$ & $34(15.8-61)$ & \\
\hline \multirow[t]{2}{*}{ K-VHI(F) } & Mean \pm SD & $2.9 \pm 2.4$ & $12.5 \pm 10.5$ & $<0.001$ \\
\hline & Median (IQR) & $2(1-4)$ & $8(4-16)$ & \\
\hline \multirow[t]{2}{*}{ K-VHI(P) } & Mean \pm SD & $2.5 \pm 2.1$ & $17.2 \pm 10.6$ & $<0.001$ \\
\hline & Median (IOR) & $3(0-4)$ & $18(9-23.4)$ & \\
\hline \multirow[t]{2}{*}{ K-VHI(E) } & Mean \pm SD & $0.6 \pm 1.0$ & $11.3 \pm 11.0$ & $<0.001$ \\
\hline & Median (IOR) & $0(0-1)$ & $10.0(2-20)$ & \\
\hline \multirow[t]{2}{*}{ K-VROOL } & Mean \pm SD & $95.1 \pm 2.5$ & $72.3 \pm 27.2$ & $<0.001$ \\
\hline & Median (IOR) & $94.5(92.5-100)$ & $70.5(52.2-88)$ & \\
\hline \multirow[t]{2}{*}{$\mathrm{K}-\mathrm{VCl}$} & Mean \pm SD & $1.5 \pm 1.6$ & $20.1 \pm 16.0$ & $<0.001$ \\
\hline & Median (IQR) & $0(0-2.1)$ & $16(8-31)$ & \\
\hline
\end{tabular}

K-VHI(T), Korean version of Voice Handicap Index (Total); K-VHI(F), Korean version of Voice Handicap Index (Functional); K-VHI(P), Korean version of Voice Handicap Index (Physical); K-VHI(E), Korean version of Voice Handicap Index (Emotional); K-VROOL, Korean version of Voice-Related Quality of Life; K-VCl, Korean version of Voice Catastrophization Index.

Table 5. Sensitivity, specificity, and AUC of the K-VHI, K-VROOL, and K-VCI cut-off points

\begin{tabular}{lcccc}
\hline & $\begin{array}{c}\text { Area under } \\
\text { the curve }\end{array}$ & Sensitivity & Specificity & Cut-off \\
\hline K-VHI & 0.920 & 91.2 & 96 & 12.1 \\
K-VROOL & 0.938 & 92.3 & 98 & 91 \\
K-VCl & 0.940 & 94 & 100 & 6.1 \\
\hline
\end{tabular}

K-VHI, Korean version of Voice Handicap Index; K-VROOL, Korean version of Voice-Related Quality of Life; K-VCI, Korean version of Voice Catastrophization Index.

\section{DISCUSSION}

In this study, we verified the diagnostic capabilities of these questionnaires for applicability in Koreans patients. The mean scores of the three questionnaires were not affected by age, symptom duration, diagnosis type, or gender and were in-line with previous studies $[9,18,25]$. This supports the generalized use of all three questionnaires in dysphonic patients and for a broad range of voice disorders.

There were significant correlations among the questionnaires used in present study. For the VHI and VRQOL, previous studies that the reported VHI was significantly correlated with the VRQOL (correlation coefficients range: -0.7--0.9) [30-32]. For the K-VHI and K-VRQOL, significant correlation between two questionnaires was also reported (correlation coefficient range: $-0.8--0.9)[29,33]$. For the VRQOL and VCI, there was a moderate correlation (correlation coefficients: -0.562) in a previous study [18]. And, for the K-VRQOL and KVCI, significant correlation between the two questionnaires was reported (correlation coefficient: -0.897) [25]. Our study showed a higher correlation coefficient $(-0.882)$ between the K-VRQOL and K-VCI, which is similar to previous research results on Koreans [25]. These results might suggest that the KVRQOL and K-VCI are not significantly affected by cultural differences. We verified the significant correlation between the K-VHI and K-VCI in this study; these results were similar to previous research [25]. Catastrophization relates to aspects of the patient's inner life (e.g., inner thoughts and beliefs) and is distinct from QOL and handicap which relates to aspects of the patient's outer life. Our study supports many previous studies that have reported decreased functional health and well-being, as well as psychometrically-based physical and mental health in dysphonic patients [34-37].

The mean scores for all three questionnaires differed significantly between the case group and the control group in our study. Woisard et al. [38] showed that a VHI total score of dysphonia was 39.7 points, and that the 'physical' subtype was the highest score among the three subtypes. This was consistent with our K-VHI findings. Other researchers also noted the highest level of handicap in the 'physical' subscale [26,39]. The mean score for the K-VRQOL was 72.3 points in our case group, similar to studies by Aaby et al. (mean score: 74.5) [31] and Sielska-Badurek et al. (mean score: 75.5) [40]. The mean 
score for the K-VCI was 20.1 points in our case group, similar to the finding of Shoffel-Havakuk et al. (mean score: 22.5) [18] and Lee et al. (mean score: 21.6) [25]. These results might suggest that the three questionnaires were not significantly affected by cultural differences.

We found that at the cut-off points, all three questionnaires had relatively high sensitivities and specificities (above 0.9), and the AUCs (above 0.9) indicated excellent accuracy and high powers of discrimination. Our cut-off point for the K-VHI was equal to 12.1 , similar to previous studies [26,27]. Previous studies reported a VHI cut-off point of 12 to be clinically relevant and useful for distinguishing patients with voice disorders from the controls group. Additionally, Ohlsson et al. [28] suggested that a VHI cut-off point of 13 be used to screen patients with voice problems. Thus, the VHI appears to have high validity and is relatively unaffected by cultural differences.

Our cut-off point for the K-VRQOL was equal to 91. Similarly, Behlau et al. [41] reported a cut-off point of 91.25 for the VRQOL to distinguish patients with voice disorders from the controls group. However, Morawska et al. [42] reported a cutoff point of 79 in a homogenous group of occupational voice users. The inter-study discrepancies in the VRQOL cut-off point may result from differing participant characteristics. Contrary to the present study and the study by Behlau et al. [41], the study by Morawska et al. [42] was conducted on a homogenous group of occupational voice users [42]. For this reason, the VRQOL scores of professional voice users with voice disorders may be lower than those of non-professional voice users with voice disorders; further these results may affect the cut-off point of the VRQOL [42].

Our cut-off point for the K-VCI was equal to 6.1. The K-VCI also had a relatively high sensitivity and specificity, and the AUC indicated excellent accuracy and a high power of discrimination. Although there were no previous reports on the VCI cut-off point that distinguishes the case group from the control group, the VCI is a valid tool for estimating the degree of catastrophization in patients with dysphonia [18,25]. Considering the results of previous studies and our study, it is important to also be deal with not only outer world factors such as QOL, but also the patient's internal world (e.g., catastrophization) when screening and treating dysphonia. Inter-disciplinary team collaborations are necessary to implement improved screening, diagnosis, and therapy for patients with voice disorders. Through this process, we believe that the voice related problems of patients, which include everyday vocal tasks, external interactions, cognition, and the internal aspects of disability and interaction can be improved.

In this study, we analyzed the cut-off points for the K-VHI, K-VRQOL, and K-VCI for screening the dysphonic from normal voice and verified the diagnostic capability of the three questionnaires for Koreans. Thus, the results of this study can be used as criteria for screening for dysphonia. It is important to note that we only included Koreans in this study. In future studies, a large sample size will be necessary and multiple cultures will need to be included to evaluate the criteria needed to screen for dysphonia.

\section{CONCLUSIONS}

In this study, we provide evidence that the K-VHI, K-VRQOL, and K-VCI can be used to distinguish patients with voice disorders from the control group. Our results have excellent accuracy and a high power of discrimination and can be used to screen for dysphonia in Korean patients.

\section{ACKNOWLEDGMENTS}

The authors would like to thank all patients participated in this study.

\section{STATEMENT OF ETHICS}

The authors have no ethical conflicts to disclose.

\section{DISCLOSURE STATEMENT}

The authors have no conflicts of interest to declare.

\section{FUNDING SOURCES}

No funding was given.

\section{AUTHOR CONTRIBUTIONS}

All the authors fulfill the ICMJE Criteria for Authorship.

\section{REFERENCES}

1. Cohen SM, Dupont WD, Courey MS. Quality-of-life impact of non-neoplastic voice disorders: a meta-analysis. Annals of Otology, Rhinology \& Laryngology. 2006;115:128-134.

2. Moradi N, Pourshahbaz A, Soltani M, Javadipour S, Hashemi H, Soltaninejad N. Cross-cultural equivalence and evaluation of psy- 
chometric properties of voice handicap index into Persian. Journal of Voice. 2013;27:258. e15-e22.

3. Karlsen T, Grieg ARH, Heimdal J-H, Aarstad HJ. Cross-cultural adaption and translation of the Voice Handicap Index into Norwegian. Folia Phoniatrica et Logopaedica. 2012;64:234-240.

4. Schindler A, Ottaviani F, Mozzanica F, Bachmann C, Favero E, Schettino I, et al. Cross-cultural adaptation and validation of the Voice Handicap Index into Italian. Journal of Voice. 2010;24:708714.

5. Jacobson BH, Johnson A, Grywalski C, Silbergleit A, Jacobson G, Benninger MS, et al. The voice handicap index (VHI): development and validation. American Journal of Speech-Language Pathology. 1997;6:66-70.

6. Moradi N, Pourshahbaz A, Soltani M, Javadipour S. Cutoff point at voice handicap index used to screen voice disorders among persian speakers. Journal of Voice. 2013;27:130. e1-e5.

7. Günther S, Rasch T, Klotz M, Hoppe U, Eysholdt U, Rosanowski F. Determination of subjective impairment in dysphonia. A methodological comparison. HNO. 2005;53:895-900, 2-4.

8. Rosen CA, Lee AS, Osborne J, Zullo T, Murry T. Development and validation of the Voice Handicap Index-10. The Laryngoscope. 2004;114:1549-1556.

9. Hogikyan ND, Sethuraman G. Validation of an instrument to measure voice-related quality of life (V-RQOL). Journal of voice. 1999;13:557-569.

10. Yun Y, Kim H, Son Y, Choi H. Validation of the Korean Voice Handicap Index (K-VHI) and the clinical usefulness of Korean VHI-10. Korean Journal of Communication Disorders. 2008;13: 216-241.

11. Trinite B, Sokolovs J. Adaptation and validation of the Voice Handicap Index in Latvian. Journal of Voice. 2014;28:452-457.

12. Bonetti A, Bonetti L. Cross-cultural adaptation and validation of the Voice Handicap Index into Croatian. Journal of Voice. 2013;27: 130. e7-e14.

13. Rosen CA, Murry T, Zinn A, Zullo T, Sonbolian M. Voice handicap index change following treatment of voice disorders. Journal of voice. 2000;14:619-623.

14. Thomas G, Kooijman PG, Donders ART, Cremers CW, de Jong FI. The voice handicap of student-teachers and risk factors perceived to have a negative influence on the voice. Journal of Voice. 2007; 21:325-336.

15. Zraick RI, Risner BY, Smith-Olinde L, Gregg BA, Johnson FL, McWeeny EK. Patient versus partner perception of voice handicap. Journal of voice. 2007;21:485-494.

16. Karnell MP, Melton SD, Childes JM, Coleman TC, Dailey SA, Hoffman HT. Reliability of clinician-based (GRBAS and CAPE-V) and patient-based (V-RQOL and IPVI) documentation of voice disorders. Journal of Voice. 2007;21:576-590.

17. Gasparini G, Behlau M. Quality of life: validation of the Brazilian version of the voice-related quality of life (V-RQOL) measure. Journal of Voice. 2009;23:76-81.

18. Shoffel-Havakuk H, Chau S, Hapner ER, Pethan M, Johns III MM. Development and validation of the voice catastrophization index.
Journal of Voice. 2017.

19. Spanos NP, Radtke-Bodorik HL, Ferguson JD, Jones B. The effects of hypnotic susceptibility, suggestions for analgesia, and the utilization of cognitive strategies on the reduction of pain. Journal of abnormal psychology. 1979;88:282.

20. Chaves JF, Brown JM. Spontaneous cognitive strategies for the control of clinical pain and stress. Journal of behavioral medicine. 1987;10:263-276.

21. Deary I, Wilson J, Carding P, Mackenzie K. The dysphonic voice heard by me, you and it: differential associations with personality and psychological distress. Clinical Otolaryngology \& Allied Sciences. 2003;28:374-378.

22. Mirza N, Ruiz C, Baum ED, Staab JP. The prevalence of major psychiatric pathologies in patients with voice. Ear, nose \& throat journal. 2003;82:10.

23. Dietrich M, Abbott KV, Gartner-Schmidt J, Rosen CA. The frequency of perceived stress, anxiety, and depression in patients with common pathologies affecting voice. Journal of Voice. 2008; 22:472-488.

24. Sullivan MJ, Bishop SR, Pivik J. The pain catastrophizing scale: development and validation. Psychological assessment. 1995;7:524.

25. Lee YW, Kim GH, Bae IH, Park HJ, Kwon SB. Korean Voice Catastrophization Index (K-VCI): Validation of the Voice Catastrophization Index for Koreans. Journal of Voice. 2019.

26. Niebudek-Bogusz E, Kuzańska A, Woznicka E, Sliwinska-Kowals$\mathrm{ka} \mathrm{M}$. Assessment of the voice handicap index as a screening tool in dysphonic patients. Folia Phoniatrica et Logopaedica. 2011;63: 269-272.

27. Gräßel E, Hoppe U, Rosanowski F. Graduierung des Voice-Handicap-Index. Hno. 2008;56:1221-1228.

28. Ohlsson A-C, Dotevall H. Voice handicap index in Swedish. Logopedics Phoniatrics Vocology. 2009;34:60-66.

29. Kim J-O, Lim S-E, Park S-Y, Choi S-H, Choi J-N, Choi H-S. Validity and reliability of Korean-version of voice handicap index and voice-related quality of life. Speech Sciences. 2007;14:111-125.

30. Portone CR, Hapner ER, McGregor L, Otto K, Johns III MM. Correlation of the voice handicap index (VHI) and the voice-related quality of life measure (V-RQOL). Journal of voice. 2007;21:723-727.

31. Aaby C, Heimdal J-H. The voice-related quality of life (V-RQOL) measure-a study on validity and reliability of the Norwegian version. Journal of Voice. 2013;27:258. e29-e33.

32. Tutya AS, Zambon F, Oliveira G, Behlau M. Comparison of VRQOL, VHI and VAPP scores in teachers Comparação dos escores dos protocolos QVV, IDV e PPAV em professores. Rev Soc Bras Fonoaudiol. 2011;16:273-281.

33. Kim J, Choi H-S. Comparison of clinicians' perceptual evaluations and patients' subjective evaluations of voice disorders. Communication Sciences \& Disorders. 2009;14:223-235.

34. Wilson J, Deary I, Millar A, Mackenzie K. The quality of life impact of dysphonia. Clinical Otolaryngology \& Allied Sciences. 2002;27: 179-182.

35. House AO, Andrews HB. Life events and difficulties preceding the onset of functional dysphonia. Journal of psychosomatic research. 
1988;32:311-319.

36. MacKenzie K, Millar A, Wilson JA, Sellars C, Deary IJ. Is voice therapy an effective treatment for dysphonia? A randomised controlled trial. Bmj. 2001;323(7314):658.

37. Merrill RM, Anderson AE, Sloan A. Quality of life indicators according to voice disorders and voice-related conditions. The Laryngoscope. 2011;121:2004-2010.

38. Woisard V, Bodin S, Yardeni E, Puech M. The voice handicap index: correlation between subjective patient response and quantitative assessment of voice. Journal of Voice. 2007;21:623-631.

39. Kooijman PG, Thomas G, Graamans K, De Jong F. Psychosocial impact of the teacher's voice throughout the career. Journal of
Voice. 2007;21:316-324.

40. Sielska-BadurekE, Rzepakowska A, Sobol M, Osuch-Wójcikiewicz E, Niemczyk K. Adaptation and validation of the voice-related quality of life measure into Polish. Journal of Voice. 2016;30:773. e7-e12.

41. Behlau M, Madazio G, Moreti F, Oliveira G, dos Santos LdMA, Paulinelli BR, et al. Efficiency and cutoff values of self-assessment instruments on the impact of a voice problem. Journal of Voice. 2016;30:506. e9-e18.

42. Morawska J, Niebudek-Bogusz E, Wiktorowicz J, Sliwinska-Kowalska M. Screening value of V-RQOL in the evaluation of occupational voice disorders. 2017. 


\section{APPENDIX A}

\section{Korean-Voice Handicap Index (K-VHI)}

현재 자신의 목소리 상태와 이 목소리가 삶에 어떠한 영향을 주는지에 대한 개인의 경험에 대한 사항입니다. 아래에 기술된 질문사항들을 읽고 해당하는 곳에 표시해 주십시오. $(0=$ 전혀 없다 $1=$ 거의 없다 $2=$ 가끔씩 $3=$ 거의 항상 $4=$ 항상)

\begin{tabular}{|c|c|c|c|c|c|}
\hline Part I - Functional & 0 & 1 & 2 & 3 & 4 \\
\hline \multicolumn{6}{|l|}{ 1. 사람들이 내 음성을 들을 때 힘들어한다. } \\
\hline \multicolumn{6}{|l|}{ 2. 시끄러운 곳에서 사람들이 내 음성을 이해하기 어려워한다. } \\
\hline \multicolumn{6}{|l|}{ 3. 집에서 가족 중 누군가를 불렀을 때, 내 말소리를 알아듣는데 힘들어한다. } \\
\hline \multicolumn{6}{|l|}{ 4. 나는 비교적 전화로 애기하는 것을 자제한다. } \\
\hline \multicolumn{6}{|l|}{ 5. 내 음성 때문에 많은 사람들을 만나는 것을 피한다. } \\
\hline \multicolumn{6}{|l|}{ 6. 내 음성 때문에 친구, 이웃, 친척들과 거의 말을 하지 않는다. } \\
\hline \multicolumn{6}{|l|}{ 7. 대화시, 주변사람들이 나에게 다시 한번 이야기 해달라고 한다. } \\
\hline \multicolumn{6}{|l|}{ 8. 내 음성 때문에 개인적 혹은 사회생활에 제한이 있는 것 같다. } \\
\hline \multicolumn{6}{|l|}{ 9. 다른 사람들과의 대화에 쉽게 끼어들기 힘들다. } \\
\hline \multicolumn{6}{|l|}{ 10. 내 음성 때문에 수입이 감소되는 것 같다. } \\
\hline Part II - Physical & 0 & 1 & 2 & 3 & 4 \\
\hline \multicolumn{6}{|l|}{ 1. 말하는 동안 숨이 차는 것 같다. } \\
\hline \multicolumn{6}{|l|}{ 2. 하루 동안 음성사용에 있어서 음성 변화가 심하다. } \\
\hline \multicolumn{6}{|l|}{ 3. 내 음성에 대해 사람들이 “목소리가 왜 그래?”라고 질문한다. } \\
\hline \multicolumn{6}{|l|}{ 4. 내 음성은 마르고 잠기는 소리가 난다. } \\
\hline \multicolumn{6}{|l|}{ 5. 목소리를 내기 위해 목에 힘이 많이 들어간다. } \\
\hline \multicolumn{6}{|l|}{ 6. 목소리가 깨끗하게 나올지 여부에 대해 예측이 안된다. } \\
\hline \multicolumn{6}{|l|}{ 7. 목소리가 좋게 들리게 하려고 음성을 바꿔보기도 한다. } \\
\hline \multicolumn{6}{|l|}{ 8. 말할 때 힘을 주어 이야기하는 것 같다. } \\
\hline \multicolumn{6}{|l|}{ 9. 내 음성은 오후에 더욱 안 좋아지는 것 같다. } \\
\hline \multicolumn{6}{|l|}{ 10. 말하는 중간에 내 목소리가 끊어지는 것 같다. } \\
\hline Part III - Emotional & 0 & 1 & 2 & 3 & 4 \\
\hline \multicolumn{6}{|l|}{ 1. 내 음성 때문에 타인과 대화시 긴장하게 되는 것 같다. } \\
\hline \multicolumn{6}{|l|}{ 2. 사람들이 나의 목소리에 신경쓰는 것 같다. } \\
\hline \multicolumn{6}{|l|}{ 3. 다른 사람들이 내 음성문제에 대해 잘 알지 못하는 것 같다. } \\
\hline \multicolumn{6}{|l|}{ 4. 내 음성문제는 나를 당황하게 한다. } \\
\hline \multicolumn{6}{|l|}{ 5. 내 음성 때문에 외출을 덜 하는 것 같다. } \\
\hline \multicolumn{6}{|l|}{ 6. 내 목소리는 나에게 핸디캡이 된다고 생각한다. } \\
\hline \multicolumn{6}{|l|}{ 7. 다른 사람들이 다시 말해달라고 할 때, 나는 화가 나는 것 같다. } \\
\hline \multicolumn{6}{|l|}{ 8. 다른 사람들이 다시 말해보라고 할 때, 나는 당혹스러움을 느낀다. } \\
\hline \multicolumn{6}{|l|}{ 9. 내 목소리 때문에 다른 사람이 나를 무능력하다고 생각할 것 같다. } \\
\hline 10. 내 목소리 때문에 나는 부끄러움을 느낀다. & & & & & \\
\hline
\end{tabular}




\section{APPENDIX B}

\section{Korean-Voice Related Quality of Life (K-VROOL)}

다음의 질문에 대해 본인이 느끼는 생각과 감정이 어느 정도인지 표시하십시오.

$1=$ 문제가 전혀 없다 $2=$ 약간 문제가 있다 $3=$ 중간 정도 문제가 있다

$4=$ 문제가 많다 $5=$ 문제가 더 이상 나쁠 수 없을 만큼 심각하다

\begin{tabular}{|c|c|c|c|c|c|}
\hline & 1 & 2 & 3 & 4 & 5 \\
\hline \multicolumn{6}{|c|}{ 1. 내 목소리 때문에 시끄러운 상황에서 크게 말하기가 힘들거나 남들이 내 말을 잘 알아듣기 힘들어한다. } \\
\hline \multicolumn{6}{|l|}{ 2. 말할 때 숨이 차고 숨을 자주 쉰다. } \\
\hline \multicolumn{6}{|c|}{ 3. 때때로 말을 시작할 때 어떤 소리가 나올지 예측하기 힘들다. } \\
\hline \multicolumn{6}{|c|}{ 4. (내 목소리 때문에) 때때로 불안하거나 당황스럽다. } \\
\hline \multicolumn{6}{|c|}{ 5. (내 목소리 때문에) 때때로 우울해진다. } \\
\hline \multicolumn{6}{|c|}{ 6. (내 목소리 때문에) 전화 통화하는데 어려움이 있다. } \\
\hline \multicolumn{6}{|c|}{ 7. (내 목소리 때문에) 직업이나 전문적인 일을 하는 동안 어려움이 있다. } \\
\hline \multicolumn{6}{|c|}{ 8. (내 목소리 때문에) 외부로 나가 사회 생활하는 것을 피하게 된다. } \\
\hline \multicolumn{6}{|c|}{ 9. 남들이 이해할 수 있도록 반복해서 말을 해야만 한다. } \\
\hline 10. 내 목소리 때문에 덜 외향적이다. & & & & & \\
\hline
\end{tabular}




\section{APPENDIX C}

\section{Korean-Voice Catastrophization Index (K-VCl)}

다음의 질문에 대해 본인이 느끼는 생각과 감정이 어느 정도인지 표시하십시오.

$0=$ 전혀 없다 $1=$ 거의 없다 $2=$ 가끔씩 $3=$ 자주 $4=$ 항상

\begin{tabular}{|c|c|c|c|c|c|}
\hline & 0 & 1 & 2 & 3 & 4 \\
\hline \multicolumn{6}{|c|}{ 1. 나는 목소리 문제의 끝은 있는 것인가 하고 항상 걱정한다. } \\
\hline \multicolumn{6}{|c|}{ 2. 나는 앞으로 목소리 문제를 이겨낼 수 없을 것 같다. } \\
\hline \multicolumn{6}{|c|}{ 3. 목소리 문제가 너무 심각하여, 목소리 문제가 더 이상 호전될 것 같지 않다는 생각이 든다. } \\
\hline \multicolumn{6}{|c|}{ 4. 목소리 문제가 너무 심하여, 목소리가 나를 압도하는 느낌이 든다. } \\
\hline \multicolumn{6}{|c|}{ 5. 더 이상 목소리 문제를 견딜 수 없을 것 같다고 생각된다. } \\
\hline \multicolumn{6}{|c|}{ 6. 목소리 문제가 더 심각해질까 봐 두렵다. } \\
\hline \multicolumn{6}{|c|}{ 7. 목소리 문제가 있었던 상황들에 대하여 계속 생각이 든다. } \\
\hline \multicolumn{6}{|c|}{ 8. 나는 진정으로 목소리 문제가 사라졌으면 좋겠다. } \\
\hline \multicolumn{6}{|c|}{ 9. 머리 속에서 목소리 문제에 대한 생각을 지워버릴 수가 없다. } \\
\hline \multicolumn{6}{|c|}{ 10. 얼마나 목소리가 안 좋았었는가에 대해 끊임없이 생각한다. } \\
\hline \multicolumn{6}{|c|}{ 11. 나는 항상 목소리 문제를 멈추게 하고 싶다고 생각한다. } \\
\hline \multicolumn{6}{|c|}{ 12. 목소리 문제의 정도를 줄이기 위해 스스로 할 수 있는 일이 아무것도 없다. } \\
\hline 13. 더 심각한 일이 생길까 걱정이다. & & & & & \\
\hline
\end{tabular}

